Louisiana State University

LSU Digital Commons

$11-22-2005$

\title{
Association of the 17-kDa extrinsic protein with photosystem II in higher plants
}

\author{
Glen D. Meades \\ Louisiana State University \\ Anne McLachlan \\ University of Cincinnati \\ Larry Sallans \\ University of Cincinnati \\ Patrick A. Limbach \\ University of Cincinnati \\ Laurie K. Frankel \\ Louisiana State University
}

See next page for additional authors

Follow this and additional works at: https://digitalcommons.Isu.edu/biosci_pubs

\section{Recommended Citation}

Meades, G., McLachlan, A., Sallans, L., Limbach, P., Frankel, L., \& Bricker, T. (2005). Association of the 17-kDa extrinsic protein with photosystem II in higher plants. Biochemistry, 44 (46), 15216-15221. https://doi.org/10.1021/bi051704u 
Authors

Glen D. Meades, Anne McLachlan, Larry Sallans, Patrick A. Limbach, Laurie K. Frankel, and Terry M. Bricker 


\title{
Association of the 17-kDa Extrinsic Protein with Photosystem II in Higher Plants ${ }^{\dagger}$
}

\author{
Glen D. Meades, Jr., ${ }^{\ddagger}$ Anne McLachlan, ${ }^{\S}$ Larry Sallans,${ }^{\S}$ Patrick A. Limbach, ${ }^{\S}$ Laurie K. Frankel,${ }^{\ddagger}$ and \\ Terry M. Bricker*, \\ Department of Biological Sciences, Biochemistry and Molecular Biology Section, Louisiana State University, Baton Rouge, \\ Louisiana 70803, and Rieveschl Laboratories for Mass Spectrometry, Department of Chemistry, University of Cincinnati, \\ Cincinnati, Ohio 45221 \\ Received August 25, 2005; Revised Manuscript Received September 22, 2005
}

\begin{abstract}
The structural association of the spinach 17-kDa extrinsic protein of photosystem II with other extrinsic and membrane-bound components of the photosystem was investigated by labeling the $17-\mathrm{kDa}$ extrinsic protein with the amino-group-specific reagent $N$-hydroxysuccinimidobiotin both on intact photosystem II membranes or as a free protein in solution. After isolation of the biotinylated molecules, the modified 17-kDa proteins were allowed to rebind to photosystem II membranes which were depleted of the $17-\mathrm{kDa}$ component. Differential binding of the protein biotinylated in solution compared to unmodified 17-kDa protein or 17-kDa protein modified on PS II membranes was observed. This indicated possible steric or ionic interference because of biotinylated lysyl residues present on the protein modified in solution. Biotinylated sites on the different modified $17-\mathrm{kDa}$ proteins were identified by trypsin and Staphylococcus V8 protease digestion, followed by affinity chromatography enrichment of the biotinylated peptides and analysis of the peptide fragment mixture by nanospray liquid chromatography-tandem mass spectrometry. Four lysyl residues that were modified when the protein was biotinylated in solution were not biotinylated when the protein was modified on the PS II membrane $\left({ }^{90} \mathrm{~K},{ }^{96} \mathrm{~K},{ }^{101} \mathrm{~K}\right.$, and $\left.{ }^{102} \mathrm{~K}\right)$. These residues appear to identify a protein domain involved in the interaction of the $17-\mathrm{kDa}$ protein with the other components of the photosystem.
\end{abstract}

Photosystem II (PS II) ${ }^{1}$ is composed of both intrinsic and extrinsic protein components, which participate in the photoenergetically driven oxidation/reduction reaction of photosynthesis. Associated with this oxygen-evolving complex in higher plants are three extrinsic membrane proteins, with molecular masses of 33,24 , and $17 \mathrm{kDa}$, that are encoded by the $p s b \mathrm{O}, p s b \mathrm{P}$, and $p s b \mathrm{Q}$ genes, respectively (1). The 24- and $17-\mathrm{kDa}$ proteins can be removed by treatment with $1.0 \mathrm{M} \mathrm{NaCl}$. This results in a dramatically lower oxygen-evolving ability of PS II membranes (2). Recovery of this lost oxygen evolution capability can be accomplished via reconstitution with the $24-$ and $17-\mathrm{kDa}$ protein (3) or through the addition of calcium (4) and chloride (5). Removal of the 33-kDa protein requires a high concentration of alkaline Tris (6), $\mathrm{CaCl}_{2}(7)$, or $\mathrm{NaCl}$-urea (8). While the loss of the two smaller extrinsic components (24

$\dagger$ This work was supported by grants from the National Science Foundation and the Department of Energy to T.M.B. and L.K.F. and the National Institutes of Health to P.A.L.

* To whom correspondence should be addressed: Department of Biological Sciences, Louisiana State University, Baton Rouge, LA 70803. Telephone: 225-578-1555. Fax: 225-578-7258. E-mail: btbric@ lsu.edu.

Louisiana State University.

$\S$ University of Cincinnati.

${ }^{1}$ Abbreviations: Chl, chlorophyll; MES, 2-( $N$-morpholine)ethanesulfonic acid; NHS-biotin, $N$-hydrosuccinimidobiotin; PAGE, polyacrylamide gel electrophoresis; PS II, photosystem II; PVDF, polyvinylidene fluoride; TCA, trichloroacetic acid; TES, 2-[(2-hydroxy1,1-bis(hydroxyl-methyl)ethyl)amino]ethanesulfonic acid; Tricine, $N$-[2-hydroxy-1,1-bis(hydroxymethyl)ethyl]-glycine; Tris, 2-amino-2(hydroxymethyl)-1,3-propanediol. and $17 \mathrm{kDa}$ ) leads to a significant loss of oxygen evolution that can be compensated for with calcium and chloride ions, the $33-\mathrm{kDa}$ extrinsic protein is required for the high rates of oxygen evolution in vivo and in isolated PS II preparations $(9,10)$.

In higher plants, the presence of the 33-kDa component is required for binding of the $24-\mathrm{kDa}$ protein. Similarly, the presence of the 24-kDa component is needed for the 17$\mathrm{kDa}$ protein to bind to the complex (11). The high-resolution crystal structures of the $17-\mathrm{kDa}$ protein $(12,13)$ exhibit a compact 4-helix bundle core with an $\mathrm{N}$-terminal domain which was not fully resolved in the crystal structure (Figure 1A). The $\mathrm{N}$-terminal 12 amino acid residues had earlier been identified as being necessary for the binding of the $17-\mathrm{kDa}$ protein to PS II (14). The loss of these residues led to a marked decrease in the ability of this component to bind to the photosystem. However, it is unclear if the $\mathrm{N}$ terminus of the $17-\mathrm{kDa}$ protein is the only determinant responsible for the binding of this component to the photosystem.

Salt-washing with $1.0 \mathrm{M} \mathrm{NaCl}$, in addition to removing the 24- and $17-\mathrm{kDa}$ components, also releases a prolyl endoprotease specific for the proline-rich $\mathrm{N}$-terminal segment of the 17-kDa protein (15). Lowering the salt concentration through subsequent dialysis appears to activate the protease, cleaving off the $\mathrm{N}$-terminal 12 residues of the $17-\mathrm{kDa}$ protein. A novel method of removing the $17-\mathrm{kDa}$ protein without the concerted removal of the $24-\mathrm{kDa}$ protein and which prevents digestion of the $17-\mathrm{kDa}$ protein by the prolyl endoprotease is employed in this paper. 

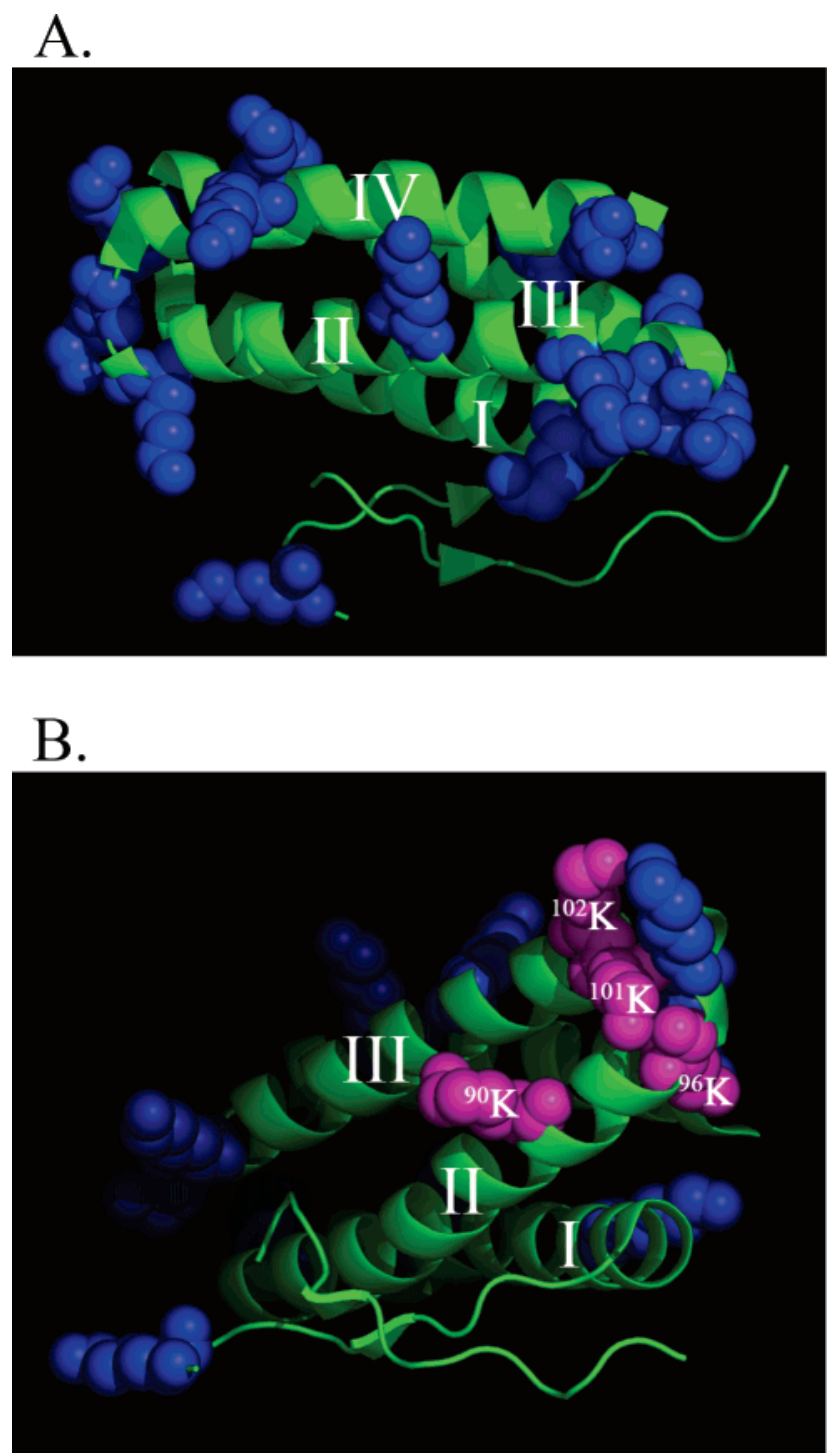

FIGURE 1: Structure of the $17-\mathrm{kDa}$ protein (PDB 1VYK). (A) Cartoon diagram showing the 4-helix bundle and the relatively unstructured $\mathrm{N}$-terminal domain. Note that residues ${ }^{14} \mathrm{~S}-{ }^{33} \mathrm{Y}$ are not resolved in the current structure. The four $\alpha$-helixes are labeled I-IV. A total of 14 lysyl residues are present in the protein; these are shown in a space-filling representation superimposed upon the cartoon diagram. All 14 of these lysyl residues are labeled when the protein is modified in solution. (B) Four lysyl residues, which are not accessible to the modification reagent when the protein is labeled while associated with the PS II membrane, are shown in magenta with their residue numbers. In this view, helix IV is partially obscured and is not labeled.

In this study, NHS-biotin was used to modify the 17$\mathrm{kDa}$ extrinsic protein both in association with the PS II membranes and as a free protein in solution. Rebinding experiments indicated that the unmodified $17-\mathrm{kDa}$ protein and $17-\mathrm{kDa}$ protein that was modified while associated with PS II rebound equivalently, while the $17-\mathrm{kDa}$ protein that was modified in solution exhibited defective rebinding kinetics. To map the location of the residues modified by NHS-biotin treatment, the different biotinylated $17-\mathrm{kDa}$ proteins were isolated and digested with either trypsin or Staphylococcus V8 protease; the peptide fragments were isolated by affinity chromatography and were then analyzed by nanospray LC-tandem mass spectroscopy. Four lysyl residues $\left({ }^{90} \mathrm{~K},{ }^{96} \mathrm{~K},{ }^{101} \mathrm{~K}\right.$, and $\left.{ }^{102} \mathrm{~K}\right)$ are labeled with $\mathrm{NHS}-$ biotin when the $17-\mathrm{kDa}$ protein is modified in solution but are not labeled when the $17-\mathrm{kDa}$ protein is associated with the PS II membrane. These residues appear to define a site of interaction between the $17-\mathrm{kDa}$ protein and PS II.

\section{MATERIALS AND METHODS}

Isolation of PS II Membranes and the 17-kDa Protein. Chloroplasts were isolated from spinach bought at a local market (16). The Chl concentration was measured by the method of Arnon (17). Oxygen-evolving PS II membranes were prepared by the method of Berthold et al. (18), with the modifications described by Ghanotakis and Babcock (19). Typical preparations had a $\mathrm{Chl} a / b$ ratio of $1.9-2.0$.

The $17-\mathrm{kDa}$ protein was removed (along with the MSP) from PS II membranes by extraction with $40 \% \mathrm{MeOH}$ and $1.0 \mathrm{M} \mathrm{NaCl}$, in $50 \mathrm{mM}$ Tricine- $\mathrm{NaOH}$ at $\mathrm{pH}$ 9.0. The presence of $40 \% \mathrm{MeOH}$ minimizes the removal of the 24$\mathrm{kDa}$ protein, while the high $\mathrm{pH}$ and salinity suppress the activity of the released prolyl endoprotease. PS II membranes were incubated for $10 \mathrm{~min}$ at $4{ }^{\circ} \mathrm{C}$, followed by centrifugation at $30000 \mathrm{~g}$ for $20 \mathrm{~min}$. The supernatant was collected and dialyzed against a 100:1 volume of deionized water. After dialysis, the extract was concentrated to $1-2 \mathrm{~mL}$ with a centrifugal ultrafiltration device (Centricon 20, 10-kDa cutoff, Polysciences, Inc.). The concentrate was then loaded onto a CM-Toyopearl $650 \mathrm{M}$ chromatography column and eluted with a $0-250 \mathrm{mM} \mathrm{NaCl}$ gradient in $20 \mathrm{mM} \mathrm{Na}-\mathrm{KPO}_{4}$ at $\mathrm{pH}$ 6.5. The MSP eluted in the void volume of the column along with a small amount of contaminating 24-kDa protein, while the 17-kDa protein eluted at about $100 \mathrm{mM} \mathrm{NaCl}$ (data not shown).

Analytical PAGE of the PS II proteins was performed under conditions described by Delepelaire and Chua (20) in gradient $12.5-20 \%$ polyacrylamide gels. The resolved proteins were electroblotted onto PVDF membranes (Immobilon-P, Millipore Co.). After blocking for $2 \mathrm{~h}$ with $5 \%$ nonfat dry milk in $150 \mathrm{mM} \mathrm{NaCl}$ and $10 \mathrm{mM}$ Tris- $\mathrm{HCl}$ at $\mathrm{pH} 7.4$, the blots were washed extensively with $150 \mathrm{mM}$ $\mathrm{NaCl}$ and $10 \mathrm{mM}$ Tris- $\mathrm{HCl}$ at $\mathrm{pH}$ 7.4. For immunological detection, a monoclonal antibody, FCC4 (21), was used as the primary antibody and an anti-mouse IgG-peroxidase conjugate was used as a secondary antibody. 4-Chloro-1naphthol and $\mathrm{H}_{2} \mathrm{O}_{2}$ were used to visualize the peroxidaselabeled bands.

Modification of the 17-kDa Protein with NHS-Biotin. For biotinylation of the $17-\mathrm{kDa}$ protein while it is associated with PS II, PS II membranes were centrifuged and resuspended in $300 \mathrm{mM}$ sucrose, $10 \mathrm{mM} \mathrm{MgCl}_{2}, 15 \mathrm{mM} \mathrm{NaCl}$, and 50 $\mathrm{mM}$ Tes- $\mathrm{NaOH}$ at $\mathrm{pH} 7.0$ at $1.0 \mathrm{mg}$ of $\mathrm{Chl} / \mathrm{mL}$ and kept at $0-4{ }^{\circ} \mathrm{C}$ throughout the procedure. Exposed amino groups (lysyl residues and the $\mathrm{N}$ terminus) on the $17-\mathrm{kDa}$ protein were labeled with NHS-biotin as described (22), with the modifications that the NHS-biotin concentration during labeling was $50 \mu \mathrm{M}$ and the labeling time was $1.5 \mathrm{~h}$. The labeling reaction was stopped by the addition of Tris- $\mathrm{HCl}$ at $\mathrm{pH} 6.8$, to a concentration of $50 \mathrm{mM}$. The residual NHSbiotin was removed by washing the membranes twice with $300 \mathrm{mM}$ sucrose, $10 \mathrm{mM} \mathrm{MgCl}_{2}, 15 \mathrm{mM} \mathrm{NaCl}$, and $50 \mathrm{mM}$ Mes-NaOH at pH 6.0 (resuspension buffer). The biotinylated $17-\mathrm{kDa}$ protein was then purified as described above.

Labeling of the purified $17-\mathrm{kDa}$ extrinsic protein in solution was performed in a similar manner at a protein 
concentration of $138 \mu \mathrm{g} / \mathrm{mL}$ in $300 \mathrm{mM}$ sucrose, $10 \mathrm{mM}$ $\mathrm{MgCl}_{2}, 15 \mathrm{mM} \mathrm{NaCl}$, and $50 \mathrm{mM}$ Tes- $\mathrm{NaOH}$ at $\mathrm{pH} 7.0$. The labeling reaction was stopped by the addition of Tris$\mathrm{HCl}$ at $\mathrm{pH} 6.8$, to a concentration of $50 \mathrm{mM}$, and the residual NHS - biotin was removed by centrifugal ultrafiltration in a Centricon 20 device with a 10-kDa cut off (Polysciences, Inc.). The purified proteins were quantified using an extinction coefficient of $12 \mathrm{mM}^{-1} \mathrm{~cm}^{-1}$ at $277 \mathrm{~nm}(23)$.

Rebinding of the Modified 17-kDa Proteins to PS II Membranes. The rebinding of unmodified and modified versions of the 17-kDa protein to PS II membranes, which were depleted of only the $17-\mathrm{kDa}$ protein, was performed. Depleted membranes were prepared by incubating PS II membranes with $20 \% \mathrm{MeOH}, 100 \mathrm{mM} \mathrm{NaCl}$, and $50 \mathrm{mM}$ Mes- $\mathrm{NaOH}$ at $\mathrm{pH} 6.0$ (24) for $1 \mathrm{~h}$. After centrifugation to recover the $17-\mathrm{kDa}$ protein-depleted membranes, they were washed twice with and resuspended in resuspension buffer. Varying amounts of the different $17-\mathrm{kDa}$ protein preparations were incubated with $17-\mathrm{kDa}$ protein-depleted membranes. After incubation for $30 \mathrm{~min}$, the $17-\mathrm{kDa}$ protein-reconstituted membranes were recovered by centrifugation at $14000 \mathrm{~g}$ for $5 \mathrm{~min}$ and washed twice with resuspension buffer. After centrifugation, the membrane pellet was resuspended in resuspension buffer and the $\mathrm{Chl}$ concentration was determined. A total of $15 \mu \mathrm{g}$ of $\mathrm{Chl}$ was loaded per lane for PAGE. The gels were electroblotted onto PVDF membranes and probed with the FCC4 antibody as described above. After drying, the "Western" blots were scanned (300 dpi resolution, 256 gray-scale levels), and the integrated optical densities of the $17-\mathrm{kDa}$ bands were determined using SigmaGel version 1.0 (Jandel Scientific, Inc.). The bound amounts of $17-\mathrm{kDa}$ protein were normalized to the amount present in unwashed PS II membranes. The PS II concentration was estimated assuming $260 \mathrm{Chl} / \mathrm{PS}$ II (25).

Protease Digestion and Purification of Biotinylated Peptides. For mass spectrometry, a sample of each biotinylated protein was brought to $10 \%$ TCA and the protein precipitate was collected by centrifugation, then washed twice with cold $100 \%$ acetone, dried under vacuum, and dissolved in $8 \mathrm{M}$ urea and $400 \mathrm{mM}$ ammonium bicarbonate (26). The solubilized protein was then diluted to $2.0 \mathrm{M}$ urea and $100 \mathrm{mM}$ ammonium bicarbonate and digested overnight at $37^{\circ} \mathrm{C}$ with either trypsin or Staphylococcus V8 protease. The final 17$\mathrm{kDa}$ protein/protease ratio was 25:1. The digestion was stopped by the addition of a protease inhibitor cocktail (Sigma Chemical Co.) prior to purification of the biotinylated peptides on a SoftLink Resin monomeric avidin column (Promega), which was prepared according to the instructions of the manufacturer.

The peptide sample was loaded on the avidin column, and the column was washed with 5 column volumes of $100 \mathrm{mM}$ $\mathrm{NH}_{4} \mathrm{HCO}_{3}$ at $\mathrm{pH}$ 7.0. The bound biotinylated molecules were then eluted with $10 \%$ acetic acid. The eluent fractions were pooled and frozen, followed by lyophilization. The lyophilized peptides were resuspended in $100 \mu \mathrm{L}$ of $0.1 \%$ trifluoroacetic acid and frozen at $-80{ }^{\circ} \mathrm{C}$.

For liquid chromatography-tandem mass spectrometry analysis, a Waters CapLC coupled to a Q-TOF II mass spectrometer was used. The samples were injected onto a $75 \mu \mathrm{m}$ i.d. $\times 10 \mathrm{~cm}$ spraying capillary packed with $5 \mu \mathrm{m}$ $\mathrm{C}_{18}$ beads. The flow rate was set to $7 \mu \mathrm{L} / \mathrm{min}$ split to

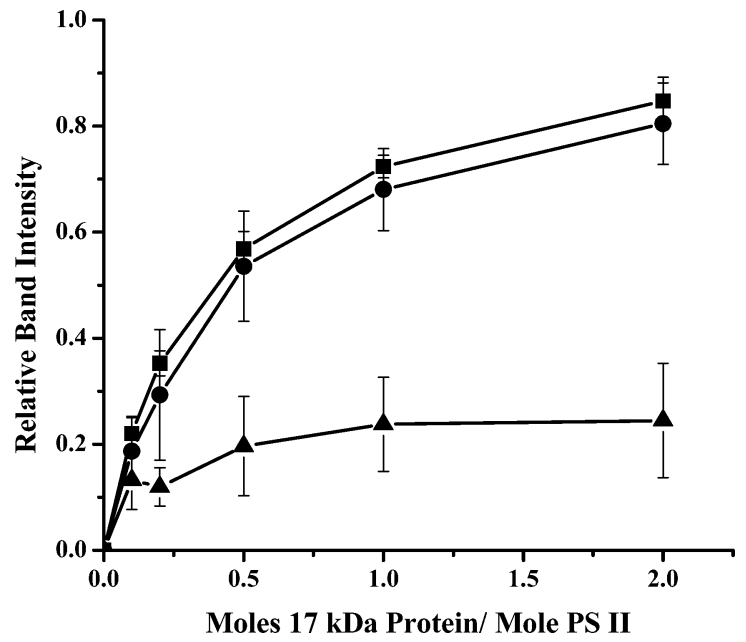

FIGURE 2: Reconstitution of $17-\mathrm{kDa}$ protein-depleted PS II membranes with control and modified 17-kDa proteins. (O) Control $17-\mathrm{kDa}$ protein, (西) $17-\mathrm{kDa}$ protein modified on the membrane, and $(\Delta)$ 17-kDa protein modified in solution. These results indicate that, while the control $17-\mathrm{kDa}$ protein and the $17-\mathrm{kDa}$ protein which had been modified on the membrane bind equivalently to $17-\mathrm{kDa}$ protein-depleted PS II membranes, the 17-kDa protein which had been modified in solution binds quite poorly. Average of at least three experiments, error bars $= \pm 1.0 \mathrm{SD}$.

approximately $200 \mathrm{~nL} / \mathrm{min}$ before reaching the column. A 75 min gradient was used to obtain good peptide separation. Buffer A consisted of $95 \%$ water, $5 \%$ acetonitrile, and $0.1 \%$ formic acid, and buffer B was $95 \%$ acetonitrile, $5 \%$ water, and $0.1 \%$ formic acid. Mass spectrometry results were analyzed with the GPMAW software package (Lighthouse Data, Sweden) and the MASCOT software suite (Matrix Science, Ltd.). PYMOL was used for production of molecular graphics (http://pymol.sourceforge.net/).

\section{RESULTS AND DISCUSSION}

The ability of the NHS-biotin-modified proteins to bind to PS II membranes is shown in Figure 2. The $17-\mathrm{kDa}$ protein-depleted PS II membranes were incubated with various amounts of either unmodified or NHS-biotinmodified $17-\mathrm{kDa}$ proteins. The membranes were washed extensively, and the amount of bound 17-kDa protein was analyzed by PAGE followed by "Western" blotting, probing with the FCC4 monoclonal antibody, color development, and image analysis. The unmodified $17-\mathrm{kDa}$ protein bound freely to PS II membranes, with saturation appearing to occur at about 1 mole of $17-\mathrm{kDa}$ protein/mole of PS II. The binding of $17-\mathrm{kDa}$ protein which had been modified with NHSbiotin while associated with the PS II membranes was indistinguishable from that observed with the unmodified protein. This indicated that the lysyl residues labeled when the $17-\mathrm{kDa}$ protein was modified on the membrane did not inhibit rebinding. Reconstitution with the $17-\mathrm{kDa}$ protein that had been modified in solution, however, yielded a radically different binding curve. Binding of this protein was markedly inhibited and exhibited only a minor increase throughout the range of protein ratios examined during the reconstitution. This result indicates that modification of the lysyl residues exposed when the 17-kDa component was labeled in solution dramatically alters the ability of the modified protein to bind to PS II. The binding that was observed with this protein preparation may be the result of a nonspecific interaction 
Table 1: Assignments of Peptides Observed after Trypsin or Staphylococcus V8 Protease Digestion of 17-kDa Protein Labeled on the Photosystem II Membrane with NHS-Biotin

\begin{tabular}{|c|c|c|c|}
\hline $\begin{array}{c}\text { observed } \\
\text { mass }\end{array}$ & $\begin{array}{c}\Delta \text { mass from } \\
\text { predicted } \\
(\mathrm{ppm})^{a}\end{array}$ & $\begin{array}{c}\text { peptide } \\
\text { assignment }\end{array}$ & $\begin{array}{c}\text { modified } \\
\mathrm{K}\end{array}$ \\
\hline & & Trypsin Digest & \\
\hline $1390.58^{b}$ & 58 & ${ }^{28} \mathrm{D}-{ }^{37} \mathrm{R}+1$ biotin & ${ }^{35} \mathrm{~K}$ \\
\hline 1440.72 & 28 & ${ }^{91} \mathrm{~T}-{ }^{101} \mathrm{~K}+1$ biotin & ${ }^{96} \mathrm{~K}$ or ${ }^{98} \mathrm{~K}^{c}$ \\
\hline 1483.79 & 13 & ${ }^{52} \mathrm{~A}-{ }^{63} \mathrm{~K}+1$ biotin & ${ }^{53} \mathrm{~K}$ \\
\hline 1552.70 & 58 & ${ }^{69} \mathrm{~K}-{ }^{79} \mathrm{R}+1$ biotin & ${ }^{69} \mathrm{~K}$ \\
\hline 1896.92 & 32 & ${ }^{111} \mathrm{~L}-{ }^{125} \mathrm{~K}+1$ biotin & ${ }^{123} \mathrm{~K}$ \\
\hline 1944.01 & 5 & ${ }^{54} \mathrm{~V}-{ }^{68} \mathrm{R}+1$ biotin & ${ }^{63} \mathrm{~K}$ \\
\hline 2072.09 & 10 & ${ }^{54} \mathrm{~V}-{ }^{69} \mathrm{~K}+1$ biotin & ${ }^{63} \mathrm{~K}$ \\
\hline 2093.96 & 38 & ${ }^{133} \mathrm{Y}-{ }^{149} \mathrm{G}+1$ biotin & ${ }^{147} \mathrm{~K}$ \\
\hline 2542.24 & 16 & ${ }^{103} \mathrm{~S}-{ }^{123} \mathrm{~K}+1$ biotin & ${ }^{110} \mathrm{~K}$ \\
\hline 2666.30 & 4 & ${ }^{126} \mathrm{~S}-{ }^{147} \mathrm{~K}+1$ biotin & ${ }^{132} \mathrm{~K}$ \\
\hline 2670.38 & 4 & ${ }^{102} \mathrm{~K}-{ }^{123} \mathrm{~K}+1$ biotin & ${ }^{110} \mathrm{~K}$ \\
\hline 2907.47 & 0 & ${ }^{124} \mathrm{I}-{ }^{147} \mathrm{~K}+1$ biotin & ${ }^{125} \mathrm{~K}$ \\
\hline & & $\begin{array}{l}\text { V8 Protease Digest } \\
{ }^{132} \mathrm{~K}-{ }^{143} \mathrm{E}+1 \text { biotin }\end{array}$ & ${ }^{132} \mathrm{~K}$ \\
\hline $\begin{array}{l}1640.69 \\
2684.32\end{array}$ & $\begin{array}{l}31 \\
19\end{array}$ & ${ }^{37} \mathrm{R}-{ }^{58} \mathrm{E}+1$ biotin & ${ }^{53} \mathrm{~K}$ \\
\hline 2940.28 & 61 & ${ }^{107} \mathrm{~L}-{ }^{131} \mathrm{E}+1$ biotin & ${ }^{110} \mathrm{~K},{ }^{123} \mathrm{~K} \cdot{ }^{c}$ or ${ }^{125} \mathrm{~K}$ \\
\hline 2940.42 & 13 & ${ }^{107} \mathrm{~L}-{ }^{131} \mathrm{E}+1$ biotin & ${ }^{110} \mathrm{~K},{ }^{c 123} \mathrm{~K}$, or ${ }^{125} \mathrm{~K}$ \\
\hline
\end{tabular}

${ }^{a}$ Predicted mass determined from the amino acid sequence of the mature protein. ${ }^{b}$ Monoisotopic mass. ${ }^{c}$ Labeled lysyl residue, ambiguity resolved by MS/MS.

with the PS II membrane. Similar binding kinetics were observed earlier in studies that documented the necessity of the $\mathrm{N}$ terminus of this protein for its binding to PS II (14).

In an effort to understand which domains on the $17-\mathrm{kDa}$ protein are interacting with PS II, we have identified the regions of this component that were differentially labeled with NHS-biotin. Tables 1 and 2 list the peptide assignments obtained by digestion of the $17-\mathrm{kDa}$ protein that had been labeled on and off of the membrane, respectively.

In these studies, two proteases, trypsin or Staphylococcus V8 protease, were employed. The use of different proteases, which differentially cleave the $17-\mathrm{kDa}$ protein, increases the number of peptides that can be analyzed in these experiments. Increasing the number of peptides that can be analyzed increases the probability that a representative and more complete sample of proteolytic fragments will be obtained for analysis.

Overnight digestion of the modified 17-kDa proteins with either trypsin or Staphylococcus V8 protease yielded a mixture of completely and partially digested proteolytic fragments. Such peptide mixtures can be analyzed with high mass accuracy by nanospray LC-tandem mass spectrometry. Modification with NHS-biotin leads to the addition of $226.08 \mathrm{Da}$ /modified lysyl residue. The amino acid sequence information from the analysis of collision-induced daughter ions allows the identification of the specific NHS-biotinmodified lysyl residues. The Mascot Program suite (http:// www.matrixscience.com) and GPMAW version 6.0 (Lighthouse Data) were used to facilitate peptide assignments.

For the protein that was modified while associated with the PS II membrane, 11 biotinylated tryptic peptides and 4 biotinylated V8 protease peptides were identified. In addition, a number of nonbiotinylated peptides were observed (data not shown). These results highlight the fact that, while the monomeric avidin column enriches the protein samples for biotinylated peptides, some nonbiotinylated peptides are retained by the matrix of the column and are not fully
Table 2: Assignments of Peptides Observed after Trypsin or Staphylococcus V8 Protease Digestion of 17-kDa Protein Labeled in Solution with NHS-Biotin

\begin{tabular}{|c|c|c|c|}
\hline $\begin{array}{l}\text { observed } \\
\text { mass }\end{array}$ & $\begin{array}{c}\Delta \text { mass } \\
\text { from } \\
\text { predicted } \\
(\mathrm{ppm})^{a}\end{array}$ & $\begin{array}{c}\text { peptide } \\
\text { assignment }\end{array}$ & $\begin{array}{c}\text { modified } \\
\mathrm{K}\end{array}$ \\
\hline \multicolumn{4}{|c|}{ Trypsin Digest } \\
\hline $1068.67^{b}$ & 66 & ${ }^{91} \mathrm{~T}-{ }^{98} \mathrm{~K}+1$ biotin & ${ }^{96} \mathrm{~K}$ \\
\hline 1227.61 & 8 & ${ }^{124} \mathrm{I}-{ }^{132} \mathrm{~K}+1$ biotin & ${ }^{125} \mathrm{~K}$ \\
\hline 1390.70 & 29 & ${ }^{28} \mathrm{D}-{ }^{37} \mathrm{R}+1$ biotin & ${ }^{35} \mathrm{~K}$ \\
\hline 1440.79 & 21 & ${ }^{91} \mathrm{~T}-{ }^{101} \mathrm{~K}+1$ biotin & ${ }^{96} \mathrm{~K}$ or ${ }^{98} \mathrm{~K}^{c}$ \\
\hline 1483.78 & 20 & ${ }^{52} \mathrm{~A}-{ }^{63} \mathrm{~K}+1$ biotin & ${ }^{53} \mathrm{~K}$ \\
\hline 1552.78 & 0 & ${ }^{69} \mathrm{~K}-{ }^{79} \mathrm{R}+1$ biotin & ${ }^{69} \mathrm{~K}$ \\
\hline 1587.83 & 25 & ${ }^{87} \mathrm{Y}-{ }^{98} \mathrm{~K}+1$ biotin & ${ }^{90} \mathrm{~K}^{c}$ or ${ }^{96} \mathrm{~K}$ \\
\hline 1666.82 & 12 & ${ }^{81} \mathrm{~T}-{ }^{101} \mathrm{~K}+2$ biotins & ${ }^{96} \mathrm{~K}$ and ${ }^{98} \mathrm{~K}$ \\
\hline 1896.98 & 0 & ${ }^{111} \mathrm{~L}-{ }^{125} \mathrm{~K}+1$ biotin & ${ }^{123} \mathrm{~K}$ \\
\hline 1943.99 & 10 & ${ }^{54} \mathrm{~V}-{ }^{68} \mathrm{R}+1$ biotin & ${ }^{63} \mathrm{~K}$ \\
\hline 2186.12 & 5 & ${ }^{87} \mathrm{Y}-{ }^{102} \mathrm{~K}+2$ biotins & ${ }^{90} \mathrm{~K}$ and ${ }^{98} \mathrm{~K}$ \\
\hline 2542.44 & 66 & ${ }^{103} \mathrm{~S}-{ }^{123} \mathrm{~K}+1$ biotin & ${ }^{110} \mathrm{~K}$ \\
\hline 2666.35 & 22 & ${ }^{126} \mathrm{~S}-{ }^{147} \mathrm{~K}+1$ biotin & ${ }^{132} \mathrm{~K}$ \\
\hline 2865.41 & 3 & ${ }^{111} \mathrm{~L}-{ }^{132} \mathrm{~K}+2$ biotin & ${ }^{123} \mathrm{~K}$ and ${ }^{125} \mathrm{~K}$ \\
\hline \\
\hline 1183.59 & 32 & ${ }^{101} \mathrm{~K}-{ }^{106} \mathrm{E}+2$ biotins & ${ }^{101} \mathrm{~K}$ and ${ }^{102} \mathrm{~K}$ \\
\hline 1342.69 & 15 & ${ }^{48} \mathrm{~A}-{ }^{58} \mathrm{E}+1$ biotin & ${ }^{53} \mathrm{~K}$ \\
\hline 2740.37 & 47 & ${ }^{107} \mathrm{~L}-{ }^{129} \mathrm{E}+1$ biotin & ${ }^{110} \mathrm{~K},{ }^{123} \mathrm{~K},{ }^{c}$ or ${ }^{125} \mathrm{~K}$ \\
\hline 2940.50 & 3 & ${ }^{107} \mathrm{~L}-{ }^{131} \mathrm{E}+1$ biotin & ${ }^{110} \mathrm{~K},{ }^{123} \mathrm{~K},{ }^{c}$ or ${ }^{125} \mathrm{~K}$ \\
\hline 3166.59 & 6 & ${ }^{107} \mathrm{~L}-{ }^{131} \mathrm{E}+2$ biotin & ${ }^{110} \mathrm{~K},{ }^{123} \mathrm{~K},{ }^{c}$ or ${ }^{125} \mathrm{~K}^{c}$ \\
\hline 4563.50 & 59 & ${ }^{107} \mathrm{~L}-{ }^{143} \mathrm{E}+2$ biotin & ${ }^{110} \mathrm{~K},{ }^{123} \mathrm{~K},{ }^{c}{ }^{125} \mathrm{~K},{ }^{c}$ or ${ }^{132} \mathrm{~K}$ \\
\hline
\end{tabular}

${ }^{a}$ Predicted mass determined from the amino acid sequence of the mature protein. ${ }^{b}$ Monoisotopic mass. ${ }^{c}$ Labeled lysyl residue, ambiguity resolved by MS/MS.

removed by the column washing buffer. The high sensitivity and nonquantitative nature of nanospray $\mathrm{LC}$-tandem mass spectrometry allows the detection of some possibly very minor peptide components. It should also be noted that, in some instances, both modified and unmodified versions of the same peptide were identified. Consequently, it is apparent that different lysyl residues were modified on different individual $17-\mathrm{kDa}$ protein molecules. This labeling heterogeneity is similar to the results obtained for modification of the 33-kDa, manganese-stabilizing protein, with NHS-biotin (27), $N$-succinimidyl propionate, 2,4,6-trinitrobenzene sulfonic acid (28), and glycine methyl ester-EDC (29).

The 17-kDa protein contains 14 lysyl residues (Figure 1), 10 of which were observed to be biotinylated when the protein was modified while associated with PS II (Table 1). These residues, ${ }^{35} \mathrm{~K},{ }^{53} \mathrm{~K},{ }^{63} \mathrm{~K},{ }^{69} \mathrm{~K},{ }^{98} \mathrm{~K},{ }^{110} \mathrm{~K},{ }^{123} \mathrm{~K}{ }^{125} \mathrm{~K},{ }^{132} \mathrm{~K}$, and ${ }^{147} \mathrm{~K}$, are consequently exposed to the bulk solvent and the labeling reagent. We have taken a very conservative approach in identifying the labeled residues. All peptide assignments are based on tandem mass spectrometry sequence information, which identifies the specifically modified lysyl residue(s). It should be noted that Table 1 contains two V8 protease peptides that were observed at a nominal mass of $2940 \mathrm{Da}$. Both of these were assigned to the peptide ${ }^{107} \mathrm{~L}-$ ${ }^{131} \mathrm{E}$, which contained one biotin modification. This peptide contains three possible biotinylatable lysyl residues, ${ }^{110} \mathrm{~K}$, ${ }^{123} \mathrm{~K}$, and ${ }^{125} \mathrm{~K}$. Analysis of the tandem mass spectrometry data indicated that one of these peptides contained a biotinylated ${ }^{123} \mathrm{~K}$ and the other contained a biotinylated ${ }^{110} \mathrm{~K}$.

Table 2 lists the peptide assignments made for peptides generated by proteolytic digestion of the $17-\mathrm{kDa}$ protein that had been biotinylated in solution. The 14 biotinylated tryptic 
peptides and 7 biotinylated V8 protease peptides were observed. All 14 lysyl residues which are present in the 17kDa protein $\left({ }^{35} \mathrm{~K},{ }^{53} \mathrm{~K},{ }^{63} \mathrm{~K},{ }^{69} \mathrm{~K},{ }^{90} \mathrm{~K},{ }^{96} \mathrm{~K},{ }^{98} \mathrm{~K},{ }^{101} \mathrm{~K},{ }^{102} \mathrm{~K}\right.$, ${ }^{110} \mathrm{~K},{ }^{123} \mathrm{~K},{ }^{125} \mathrm{~K},{ }^{132} \mathrm{~K}$, and ${ }^{147} \mathrm{~K}$ ) were identified as modified on the $17-\mathrm{kDa}$ protein that was biotinylated in solution. These results indicate that, in solution, all lysyl residues present in the protein are exposed at the protein surface and are accessible to the bulk solvent and the labeling reagent.

Consequently, four residues $\left({ }^{90} \mathrm{~K},{ }^{96} \mathrm{~K},{ }^{101} \mathrm{~K}\right.$, and $\left.{ }^{102} \mathrm{~K}\right)$ are labeled only in solution but are not labeled when the 17 $\mathrm{kDa}$ protein is associated with PS II. The locations of these residues are shown in Figure 1B. All of these residues cluster in a domain that bridges the end of helix II and the start of helix III. The NHS-biotinylation of one or more of these residues is responsible for the loss of normal binding of the 17-kDa protein to PS II (Figure 2). We hypothesize that these clustered residues are oriented to face the PS II complex (Figure 1B). A number of hypotheses could account for this observation. First, it is possible that the modified lysyl residues are directly involved in the formation of chargepair interactions with the other components in PS II. While such charge-pair interactions were not observed between the 17-kDa protein and other PS II components using EDC crosslinking (a zero-length cross-linker, Bricker and Frankel, unpublished observations), it should be noted that if the charge pair is buried at the face of the interaction (and consequently not accessible to the cross-linking reagent) it would not be identified by this technique. A second possibility is that the labeling with NHS-biotin sterically interferes with the association of the 17-kDa protein to PS II. The presence of the biotin moiety may prevent the formation of other protein-protein interactions that are required for effective binding of the $17-\mathrm{kDa}$ protein to PS II. It is impossible at this point in time to differentiate between these (and possibly other) mechanisms.

The N-terminal 12 amino acid residues of the protein had previousely been shown to be necessary for the $17-\mathrm{kDa}$ protein to bind to PS II (14). It was unclear, however, if this domain was also sufficient for the interaction of the protein with the photosystem. Our results indicate that other domains on the 17-kDa protein may also be necessary for normal binding and interaction with the photosystem.

Which other components of PS II could be interacting with the $17-\mathrm{kDa}$ protein? The $24-\mathrm{kDa}$ protein is a prime candidate. It has been previously shown that the $24-\mathrm{kDa}$ protein is required for $17-\mathrm{kDa}$ protein binding $(30,31)$. Additionally, unidentified residues on the $24-\mathrm{kDa}$ protein are within $11 \AA$ of residues on the 17-kDa protein, because these two components can be cross-linked with homobifunctional crosslinking reagents that span $11 \AA$ (32). The $33-\mathrm{kDa}$ protein has also been implicated in providing binding determinants for the 17-kDa protein. In cross-reconstitution experiments, extrinsic protein-depleted PS II membranes, which had been reconstituted with either cyanobacterial or red algal $33-\mathrm{kDa}$ proteins, could only partially rebind spinach $24-\mathrm{kDa}$ protein and could not bind spinach $17-\mathrm{kDa}$ protein. This indicates that there may exist structural determinants on the higher plant 33-kDa protein which are required for the binding of the $24-$ and $17-\mathrm{kDa}$ proteins and which are absent in the homologous cyanobacterial and red algal $33-\mathrm{kDa}$ proteins (33). Finally, it is possible that the $17-\mathrm{kDa}$ protein interacts directly with unidentified intrinsic membrane protein com- ponents of PS II. In Chlamydomonas, the 17-kDa protein can bind to its functional site on the photosystem independently of the other extrinsic proteins (34). While this ability is not observed in higher plants, it does highlight the possibility that intrinsic PS II components may interact directly with the extrinsic 17-kDa protein.

\section{REFERENCES}

1. Bricker, T. M., and Ghanotakis, D. (1996) The structure and function of the oxygen-evolving complex, in Advances in Photosynthesis. Oxygenic Photosynthesis: The Light Reactions (Yocum, C. F., and Ort, D. R., Eds.) Vol. 4, pp 113-136.

2. Kuwabara, T., and Murata, N. (1982) Inactivation of photosynthetic oxygen evolution and concomitant release of three polypeptides in the photosystem II particles of spinach chloroplasts, Plant Cell Physiol. 23, 533-539.

3. Akerlund, H.-E., Jannson, C., and Andersson, B. (1982) Reconstitution of oxygen evolution in high salt washed photosystem II particles, Biochim. Biophys. Acta 681, 1-10.

4. Ghanotakis, D. F., Babcock, G. T., and Yocum, C. F. (1984) Calcium reconstitutes high rates of oxygen evolution in polypeptide depleted photosystem II preparations, FEBS Lett. 167, 127130.

5. Miyao, M., and Murata, N. (1985) The $\mathrm{Cl}^{-}$effect on photosynthetic oxygen evolution: Interaction of $\mathrm{Cl}^{-}$with $18-\mathrm{kDa}, 24-\mathrm{kDa}$, and 33-kDa proteins, FEBS Lett. 180, 303-308.

6. Yamamoto, Y., and Kubota, F. (1987) Specific release of the extrinsic $18 \mathrm{kDa}$ protein from spinach photosystem II particles by the treatment with $\mathrm{NaCl}$ and methanol and its application for large-scale purification of the three extrinsic proteins of photosystem II without chromatography, Biochim. Biophys. Acta 893, $579-583$.

7. Ono, T.-A., and Inoue, Y. (1983) Mn-preserving extraction of 33-, $24-$, and $16-\mathrm{kDa}$ proteins from $\mathrm{O}_{2}$-evolving PS II particles by divalent salt-washing, FEBS Lett. 164, 255-260.

8. Miyao, M., and Murata, N. (1984) Role of the $33 \mathrm{kDa}$ polypeptide in preserving $\mathrm{Mn}$ in the photosynthetic oxygen-evolution, FEBS Lett. 170, 350-354.

9. Bricker, T. M. (1992) Oxygen evolution in the absence of the 33 $\mathrm{kDa}$ manganese-stabilizing protein, Biochemistry 31, 4623-4628.

10. Burnap, R., and Sherman, L. A. (1991) Deletion mutagenesis in Synechocystis sp. PCC6803 indicates the Mn-stabilizing protein of photosystem II is not essential for $\mathrm{O}_{2}$ evolution, Biochemistry $30,440-446$.

11. Miyao, M., and Murata, N. (1983) Partial disintegration and reconstitution of the photosynthetic oxygen evolution complex, Biochim. Biophys. Acta 725, 87-93.

12. Calderone, V. T., Vujicic, A. M., Battistutta, R., Giacometti, G. M., Andreucci, F., Barbato, R., Zanotti, G. (2003) Crystal structure of the PsbQ protein of photosystem II from higher plants, EMBO Rep. 900-905.

13. Hermoso, J. A., Balsera, M., de las Rivas, J., and Arellano, J. (2004) Crystal structure of the $16 \mathrm{kDa}$ protein from higher plants, PDB accession 1VYK.

14. Kuwabara, T., Murata, T., Miyao, M., and Murata, N. (1986) Partial degradation of the $18-\mathrm{kDa}$ protein of the photosynthetic oxygen-evolving complex a study of a binding site, Biochim. Biophys. Acta 850, 146-155.

15. Kuwabara, T., and Suzuki, K. (1994) A prolyl endoproteinase that acts specifically on the extrinsic $18 \mathrm{kDa}$ protein of photosystem II: Purification and further characterization, Plant Cell Physiol. $35,665-675$.

16. Bricker, T. M., Pakrasi, H. B., and Sherman, L. A. (1985) Characterization of a spinach photosystem II core preparation isolated by a simplified method, Biochim. Biophys. Acta 237, 170176 .

17. Arnon, D. I. (1949) Copper enzymes in isolated chloroplasts. Polyphenol oxidase in Beta vulgaris, Plant Physiol. 24, 1-15.

18. Berthold, D. A., Babcock, G. T., and Yocum, C. F. (1981) A highly resolved oxygen-evolving photosystem II preparations from spinach thylakoid membranes, FEBS Lett. 134, 231-234.

19. Ghanotakis, D. F., and Babcock, G. T. (1983) Hydroxylamine as an inhibitor between $\mathrm{Z}$ and P680 in photosystem II, FEBS Lett. 153, 231-234.

20. Delepelaire, P., and Chua, N. (1979) Lithium dodecyl sulfate/ polyacrylamide gel electrophoresis of thylakoid membranes at 4 
${ }^{\circ} \mathrm{C}$ : Characterizations of two additional chlorophyll $a$-protein complexes, Proc. Natl. Acad. Sci. U.S.A. 76, 111-115.

21. Frankel, L. K., and Bricker, T. M. (1990) Monoclonal antibodies directed against the 33, 24, and $17 \mathrm{kDa}$ extrinsic proteins of spinach photosystem II, in Current Research in Photosynthesis (Batcheffsky, M., Ed.) pp 825-828.

22. Bricker, T. M., Odom, W. R., and Queirolo, C. B. (1988) Close association of the $33 \mathrm{kDa}$ extrinsic protein with the apoprotein of CPa-1 in photosystem II, FEBS Lett. 231, 111-117.

23. Miyao, M., Fujimura, Y., and Murata, N. (1988) Partial degradation of the extrinsic $23 \mathrm{kDa}$ protein of the photosystem II complex of spinach, Biochim. Biophys. Acta 936, 465-474.

24. Yamamoto, Y., and Kubota, F. (1987) Specific release of the extrinsic $18-\mathrm{kDa}$ protein from spinach photosystem II particles by the treatment with $\mathrm{NaCl}$ and methanol and its application for large scale purification of the three extrinsic proteins of photosystem II without chromatography, Biochim. Biophys. Acta 893, $579-583$.

25. Xu, Q. A., and Bricker, T. M. (1992) Structural organization of proteins on the oxidizing side of photosystem II: Two molecules of the $33 \mathrm{kDa}$ manganese-stabilizing protein per reaction center, J. Biol. Chem. 267, 25816-25821.

26. Stone, K. L., LoPresti, M. B., Crawford, J. M., DeAngelis, R., and Williams, K. R. (1989) Enzymatic digestion of proteins and HPLC peptide isolation, in A Practical Guide to Protein and Peptide Purification for Microsequencing (Matsudaira, P. T., Ed.) pp 31-47.

27. Frankel, L., and Bricker, T. M. (1995) Interaction of the 33-kDa extrinsic protein with photosystem II: Identification of domains on the 33-kDa protein that are shielded from NHS-biotinylation by photosystem II, Biochemistry 34, 7492-7497.

28. Miura, T., Shen, J.-R., Takahashi, S., Kamo, M., Nakamura, E., Ohta, H., Kamei, A., Inoue, Y., Domae, N., Takio, K., Nakazato,
K., Inoue, Y., and Enami, I. (1997) Identification of domains on the extrinsic $33-\mathrm{kDa}$ protein possibly involved in electrostatic interaction with photosystem II complex by means of chemical modification, J. Biol. Chem. 272, 3788-3798.

29. Bricker, T. M., and Frankel, L. K. (2003) Carboxylate groups on the manganese-stabilizing protein are required for efficient binding of the $24 \mathrm{kDa}$ protein to photosystem II, Biochemistry 42, 20562061.

30. Andersson, B., Larsson, C., Jansson, C., Ljungberg, U., and Akerlund, H.-E. (1984) Immunological studies on the organization of proteins in photosynthetic oxygen evolution, Biochim. Biophys. Acta 766, 21-26.

31. Kavelaki, K., and Ghanotakis, D. F. (1991) Effects of the manganese complex on the binding of the extrinsic proteins (17, 23, and $33 \mathrm{kDa}$ ) of photosystem II, Photosynth. Res. 29, 149155.

32. Enami, I., Mochizuki, Y., Takahashi, S., Kakuno, T., Horio, T., Satoh, K., and Katoh, S. (1990) Evidence from crosslinking for the nearest neighbor relationships among the three extrinsic proteins of spinach photosystem II complexes that are associated with oxygen evolution, Plant Cell Physiol. 31, 725-729.

33. Enami, I., Yoshihara, S., Tohri, A., Okumura, A., Ohta, H., and Shen, J. R. (2000) Cross-reconstitution of various extrinsic proteins and photosystem II complexes from cyanobacteria, red algae, and higher plants, Plant Cell Physiol. 41, 1354-1364.

34. Suzuki, T., Minagawa, J., Tomo, T., Sonoike, K., Ohta, H., and Enami, I. (2003) Binding and functional properties of the extrinsic proteins in oxygen-evolving photosystem II particles fram a green alga, Chlamydomonas reinhardtii having His-tagged CP47, Plant Cell Physiol. 44, 76-84.

BI051704U 